\title{
Testing for Service-Led and Investment-Led Hypothesis: Evidence from 'Chindia'
}

\author{
A.H. Baharom \\ Department of Economics, Faculty of Economics and Management \\ Universiti Putra Malaysia \\ 43400 UPM Serdang, Selangor, Malaysia \\ Tel: 60-3-8946-7751_E-mail: baharom@econ.upm.edu.my \\ Muzafar Shah Habibullah (Corresponding author) \\ Department of Economics, Faculty of Economics and Management \\ Universiti Putra Malaysia \\ 43400 UPM Serdang, Selangor, Malaysia \\ Tel: 60-3-8946-7635 E-mail: muzafar@econ.upm.edu.my \\ R.C. Royfaizal \\ Department of Economics, Faculty of Economics and Management \\ Universiti Putra Malaysia \\ 43400 UPM Serdang, Selangor, Malaysia \\ Tel: 60-3-8946-7751 E-mail: royfaizal@econ.upm.edu.my
}

\begin{abstract}
This study examines the meaningful relationship between economic growth, and service sector contribution and domestic investment in two major Asian economies, namely India and China. Autoregressive Distributed Lag (ARDL) bounds testing procedure is employed to analyze the impact of the selected variables namely (1) contribution by the service sector, (2) (4) domestic investment on economic growth and vice versa. The period of interest is 1960-2005 using annual data. The empirical results demonstrate that for the case of India, there is (1) a unidirectional causality from domestic investment to economic growth and (2) from economic growth to services. As for China, only unidirectional causality from services sector to economic growth is detected, while no meaningful relationship was found between domestic investment and economic growth.
\end{abstract}

Keywords: China, India, Service-led, Investment-led, Bound Testing

\section{Introduction}

Comparing world's two population superpowers, China and India is an interesting subject and they have long fascinated and stimulated studies, but until fairly recently they were small players on the international economic scene. Both countries, by virtue of their sheer size, have the potential to be dominant forces in the international economy and are poised to change the global economic landscape. The emergence of China as a major economic power was followed by a slower, but still important, economic transformation in India. Before 1980, economic growth in both China and India, as measured by the growth rate of income per capita (in purchasing power parity terms), was relatively slow. After 1980, growth in both countries accelerated, dramatically in China and more modestly in India. China rapidly overtook India, and now has substantially higher income per capita. Until the early 1990s, GDP per capita in China and India was at comparable levels, but China adopted wide-ranging economic reform one decade earlier than India. 
The Chinese economy is much more integrated with the world economy through international trade and investment, which helps to explain its stronger rate of GDP growth during most of the past 30 years. China's ratios of domestic savings and investment to GDP are roughly double those of India's. China's early steps to liberalize its economy and invest heavily to modernize its physical infrastructure gave it a substantial edge over India in terms of income per capita levels which also made China a more attractive destination to foreign investors. China leads India in foreign investment, a key contributor to economic growth. China has been growing at roughly $9 \%$ a year with an investment/GDP ratio of around $40 \%$ while India has been registering about $6 \%$ a year with an investment/GDP ratio of about $25 \%$. This indicates that India is using capital more efficiently, in the sense that it gets more growth for the investment. India is picking up the pace, not far behind from China in the past 25 years (6\% to 9\%). Although India's potential higher rate may rest on a different set of factors than the ones that have driven China

According to the World Bank, spectacular growth in China and India has pushed the number of people around the world living on less than a dollar a day below the 1 billion level. Lately, there have been a number of articles extolling the rise of China and India in the world economy. Phrases like 'the two Asian giants' have become commonplace. Economists have also speculated about a 'tripolar' scenario of the US, China and India dominating global affairs in a decade or two from now and new terms such as 'Chindia' have been used to reiterate this sentiment. The numbers of studies on these two economies have been on the rise. Ljungwall (2006), Hu and Khan (1997), Kahrl and Roland-Holst (2008) are example of studies for China while for India the studies are of Singh and Kalirajan (2003), Chakraborty and Nunnenkamp (2008) and Pachauri (2004).

Traditionally, export, foreign direct investment and trade have often been referred to as the "engine of growth" that propelled the development of today's economically advanced nations during the nineteenth and early twentieth centuries, thus studies have flourished on economic growth and its determinants. However, very few researchers have taken into consideration the level of domestic investment, and fewer on the contribution of service sector as a stimulus of growth. Studies of investment-led growth normally rely on foreign direct investment and not domestic investment. Blomstrom et al. (1996), Collins (2004), and Liu et al. (2002) are example of three studies on causality between growth and domestic investment. While examples of services led growth literatures are such of Sasaki (2007), Chakraborty and Nunnenkamp (2008) and OECD (2008)..

This paper is organized as follows. In the next section we discuss some prior evidence on the effect of service sector contribution and investment (especially domestic) on economic growth followed by some stylized facts on India and China. In section 4, we present the unit root, cointegration and Granger causality tests in the ARDL bounds testing framework used in the study. In section 5, we discuss the empirical results and the last section contains our conclusion.

\section{Related Literature}

Chakraborty and Nunnenkamp (2008) in a sectoral level analysis in India found only transitory effects of foreign direct investment (FDI) on output in the services sector; however FDI in the services sector appears to have promoted growth through cross-sector spillovers. Blomstrom et al. (1996), Collins (2004), Liu et al. (2002) and Liu and Hsu (2006) found mixed results in their studies. While Blomstrom et al. (1996) suggest that there is a one-way causal relationship running from economic growth to fixed investment, Liu et al. (2002) suggest otherwise, a bi-directional causality between these variables. Collins (2004) found contradicting results between countries in her result on Japan and Korea with respect to the domestic investment (I-S) and external balances during the respective rapid growth era .It shows that when personal saving fell in Korea, the discrepancy with the domestic investment which in itself is set by the government planning is financed by external borrowing. Japan avoided foreign borrowing in the 1950s and 1960s by curbing investment when necessary. Therefore, there are significant qualitative differences between Japan and Korea in their economic growth process.

Li and Zhang (2008) in a study on both China and India suggested that the segmentation of global manufacturing and services provided China and subsequently India with a golden opportunity to make full use of their absolute advantagelow-cost, yet educated labour- to integrate into the world economy within a comparatively shorter period of time than some earlier industrialisers. The findings of Abu-Bader and Abu-Qarn (2008) suggest the need to accelerate the financial reforms that the Egyptian government launched in 1991 and to improve the efficiency of the financial system to stimulate saving/investment and, consequently, long-term economic growth

Sasaki (2007) and OECD (2008) are two studies on the impact of services sector on economic growth, both on the subject of Japan. Sasaki (2007) investigated and suggest that given that the growth rate of productivity in the service sector is lower than that in the manufacturing sector, both the employment share in the manufacturing and rate of economic growth will decline in the long run irrespective of the size of the elasticity of substitution between labour and service input. a sentiment which is shared by , OECD (2008), a study which suggested that enhancing productivity growth in the service sector is crucial to boost economic growth in Japan. Another study on Singapore, South Korea, Taiwan and Thailand by Tan et al (2007) shows evidence that economic growth in these Asian economies are found to be generated by capital formation or investment. 


\section{Stylised facts on India and China}

Figure 1 and Figure 2 illustrates the relationship between the growth rate of gross capital formation which is used as an indicator for domestic investment, growth rate of the services sectors contribution to GDP, and real GDP per capita, which is used as an indicator for economic growth respectively. It can be observed that for the first twenty years, growth rate of investment and growth rate of economic growth was moving in tandem, where else the following twenty years the growth rate of investment was much more volatile compared to the economic growth. As for services, its growth rate is quite calm compared to economic growth, and the trend remains the same throughout the study period. Figure 3 and Figure 4 illustrates the relationship between the growth rate of gross capital formation and the growth rate of the services sectors contribution to GDP, and real GDP per capita, respectively for the case of China.. It can be observed that for the growth rate of investment is very volatile (as high as 50\%) compared to the economic growth, while the growth of service sector, except the first ten years, it is identical to economic growth.

\section{Data and Methodology}

All series examined in this study - services sector contribution to GDP is used as a proxy to test the services led-growth hypothesis while gross capital formation is used as a proxy of domestic investment to test the investment led-growth hypothesis or vice versa, respectively - are collected from the IMF statistics and WDI. The data is annual and spans the time period 1960 to 2005. All the variables are expressed in natural logs.

In terms of methodology, the ARDL approach to cointegration (Pesaran et al., 2001) involves estimating the conditional error correction $(\mathrm{EC})$ version of the ARDL model to estimate the hypothesis is:

$$
\Delta \ln y_{t}=\delta_{0}+\lambda_{1} \ln y_{t-1}+\lambda_{2} \ln x_{t-1}+\sum_{i=1}^{\rho} \theta_{i} \Delta \ln y_{t-i}+\sum_{i=0}^{\rho} \phi_{i} \Delta \ln x_{t-i}+\varepsilon_{t}
$$

whereby $\lambda_{1}$ and $\lambda_{2}$ are long-run multipliers and $\delta_{0}$ is the drift. Lagged values of $\Delta y_{t}$ and current and lagged values of $\Delta x_{t}$ are used to model the short-run dynamic structure. All variables in natural logarithm and $\rho$ is the optimal lag length.

The $F$-test is conducted to test the existing of the long-run relationship. The alternative hypothesis for a cointegration among variables in equation (1) is $\mathrm{H}_{1}: \lambda_{1} \neq \lambda_{2} \neq 0$ against the null hypothesis $\mathrm{H}_{0}: \lambda_{1}=\lambda_{2}=0$. The $F$-test has a non-standard distribution which depends on (i) the number of regressors, (ii) whether variables included in the model are $I(1)$ or $I(0)$ and (iii) whether the model consists and intercept and/or a trend. Given a relatively small sample size in this study of 40 observations, the critical values used are as reported by Narayan (2005) which are based on a small sample size between 30 and 80 .

If the $F$-test statistic exceeds their respective upper critical values, we can conclude that there is enough evidence of a long-run relationship between the variables. If the $F$-test statistic is below the upper critical values, we failed to reject the null hypothesis of no cointegration and if it lies between the bounds, a conclusive inference cannot be made without knowing the order of integration of the underlying regressors. If there is a cointegration, the following long-run model is estimated:

$$
\ln y_{t}=\beta_{1}+\sum_{i=1}^{\rho} \phi_{1 i} \ln y_{t-i}+\sum_{i=0}^{\rho} \varphi_{1 i} \ln x_{t-i}+v_{t}
$$

The orders of the lags in the ARDL model are selected by either the Schwarz Bayesian criterion (SBC) or the Akaike information criterion (AIC), before the selected model is estimated by ordinary least squares (OLS).

The ARDL specification of the short-run dynamics can be derived by constructing an error correction model (ECM) of the following form:

$$
\Delta \ln y_{t}=\alpha_{1}+\sum_{i=1}^{\rho} \lambda_{2 i} \Delta \ln y_{t-i}+\sum_{i=0}^{\rho} \varpi_{2 i} \Delta \ln x_{t-i}+\psi E C M_{t-1}+\xi_{t}
$$

whereby $\mathrm{ECMt}_{-1}$ is the error correction term, defined as:

$$
E C M_{t}=\ln y_{t}-\beta_{1}-\sum_{i=1}^{\rho} \phi_{1 i} \ln y_{t-i}-\sum_{i=0}^{\rho} \varphi_{1 i} \ln x_{t-i}
$$


All coefficients of the short-run equation are coefficients relating to the short-run dynamics of the model's convergence to equilibrium and $\psi$ represent the speed of adjustment.

\section{Empirical Results}

Prior to the testing of cointegration, we conducted a test of order of integration for each variable using Augmented Dickey-Fuller (ADF) and Phillip-Perron (PP). Even though ARDL framework does not require pre-testing variables to be done, the unit root test could convince us whether or not the ARDL model should be used. Table 1 shows that there is a mixture of $I(0)$ and $I(1)$ of underlying regressors and therefore, there ARDL testing could be proceeded with.

The calculated $F$-test statistics for cointegration are reported Table 2. We find a cointegrating relationship between gross domestic product per capita (GDPC) and the macroeconomic variables in both the bivariate cases for India and only one of the two bivariate cases for China. In India, the (1) GDPC is cointegrated with gross capital formation with causality running from investment to growth thus supporting the investment-led growth hypothesis. However surprisingly, the services-led growth hypothesis is rejected. When the GDPC is the reggresand, we could not detect any causality running from services to economic growth compared to when services is used as the reggresand. It is a clear indicator that growth causes services and not the other way around.

In China, in both bivariate models, namely, GDPC-gross capital formation and GDPC-services, (1) it is found that the causality runs from the services to the GDPC, in contrary with the results for India. The results indicate that for the case of China the services led-growth hypothesis is valid. (2) As for the second model, the $F$-test statistics are below the critical values, indicating that the null hypothesis of no cointegration cannot be rejected at the $10 \%$ level or better, thus no meaningful relationship exists. The results of the long-run elasticities, for both the countries are presented in table 3 . Each of the independent variable is positively significant to the dependent variables. In India, for example, increase 1\% in gross capital formation and money supply will lead to the gross domestic product per capita rise by $0.65 \%$ and $0.24 \%$ respectively. Besides that, $1 \%$ rise in GDPC increases the exports and services by $2.6 \%$ and $4.58 \%$ respectively. In China, we find that $1 \%$ rise in services will increase the GDPC by $0.81 \%$.

The results of the ECM and short-run elasticities are presented in Table 4. Each of the coefficients in the ECM is statistically significant. The results show that the error correction term $-\mathrm{ECM}_{\mathrm{t}-1}-$ is negative, indicating that the feedback mechanism is very effective in India for investment led-growth and growth led-export hypothesis, and also for services led-growth hypothesis in China. For example, convergence to long-run equilibrium after a shock to money supply is instantaneous for the GDPC in India. The $\mathrm{ECM}_{\mathrm{t}-1}$ takes for the value of -0.14 , suggesting that a deviation from the long-run equilibrium level of money supply in one year is corrected by about $14 \%$ in the next year.

\section{Conclusion}

In this study the autoregressive distributed lag (ARDL) bounds testing procedure was employed to investigate the dynamic and long-run relationship between economic growth, and service sector contribution and domestic investment inv two of the most populous nations in the world namely China and India. Bivariate analysis on the impact of services on the economic growth; and the impact of investment on economic growth, vice versa was conducted for both the nations. The sample period was $1960-2005$ and the data was annual. All the data went through log-log transformation so that the estimates will be less sensitive to outliers or influential observations and also in order to reduce the data range.

The results suggest that all the variables chosen are $I(1)$ or in other words they are non-stationary variables and achieved stationarity only after first differencing. The cointegration analysis using the ARDL bounds testing approach clearly indicates that (1) investment-led hypothesis is valid in India and (2) service-led hypothesis is valid for China. The results are interesting, with these two giant economies not sharing common attributes. India's result are similar with the finding for Singapore, South Korea, Taiwan and Thailand as per the study of Tan et al (2007) while in contrary with the finding of Blomstrom et al. (1996) and Liu et al. (2002). While Blomstrom et al. (1996) suggest that there is a one-way causal relationship running from economic growth to fixed investment, Liu et al. (2002). suggest otherwise, a bi-directional causality between these variables. As for the result of China, it is in contrary with Sasaki (2007) and OECD (2008), whereby both these studies indicated that for the case Japan, services lag in productivity and could not drive economic growth.

\section{References}

Abu-Bader, S. \& Abu-Qarn, A.S. (2008) Financial development and economic growth: The Egyptian experience. Journal of Policy Modeling, 30 (5), 887-898

Blomstrom, M.,Lipsey,R.E. \& Zejan, M. (1996). Is fixed investment the key to economic growth? Quarterly Journal of Economics, 111, 269-276

Chakraborty, C. \& Nunnenkamp, P. (2008). Economic reforms, FDI, and economic growth in India: A sectoral level analysis. World Development, 36 (7), 1192-1212 
Collins, S.M. (2004). Savings and growth experiences of Korea and Japan. J.Japan. Int. Econ., 2 (3), 328-350

$\mathrm{Hu}$, Z. \& Khan, M.S. (1997). Why is China growing so fast? International Monetary Fund

International Financial Statistics (IFS), CD-ROM 2007.

Kahlrl, F. \& Roland-Host, D. (2008). Energy and exports in China. China Economic Review, forthcoming

Li., Y. \& Zhang, B. (2008). Development path of China and India and the challenges for their sustainable growth. World Economy, 31(10), 1277-1291

Liu, X., Burridge, P. \& Sinclair, P.J.N. (2002). Relationship between economic growth, foreign direct investment and trade: Evidence from China. Applied Economics, 34, 1433-1440

Ljungwall, C. (2006). Export-led growth; Application to china's provinces, 1978-2001. Journal of Chinese Economic and Business Studies, 4 (2), 109-126

Narayan, P.K. (2005). The Saving and Investment Nexus for China: Evidence from Cointegration Tests. Applied Economics, 37, 1979-1990.

OECD. (2008). Economic Surveys; Japan

Pachauri, R.K. (2004). The future of India's economic growth: the natural resources and energy dimension. Futures, 36, 703-713

Pesaran, M.H., Shin, Y. \& Smith, R. (2001). Bounds Testing Approaches to the Analysis of Level Relationship. Journal of Applied Econometrics, 16, 289-326.

Sasaki, H. (2007). The rise of service employment and its impact on aggregate productivity growth. Structural Change and Economic Dynamics, 18, 438-459

Singh, K. \& Kalirajan, K. (2003). The inflation-growth nexus in India: an empirical analysis. Journal of Policy Modeling, 25, 377-396

Tan, S.H., Habibullah, M.S., Azali, M. \&Baharumshah, A.Z. (2007). Testing for Financial-led, Export-led and Import-led growth hypothesis on four Asian economies. International Journal of Economics \& Management, 1(3), 307-336

World Development Indicator (WDI), CD-ROM 2007.

Table 1: ADF and PP unit root tests

\begin{tabular}{|c|c|c|c|c|}
\hline \multirow[t]{2}{*}{ Variables } & \multicolumn{2}{|c|}{ India } & \multicolumn{2}{|c|}{ China } \\
\hline & $\mathrm{ADF}$ & PP & $\mathrm{ADF}$ & PP \\
\hline $\ln G D P C_{t}$ & $-0.2382(0)$ & $0.7070(8)$ & $-1.5517(1)$ & $2.3990(8)$ \\
\hline$\Delta \ln G D P C_{t}$ & $-7.1708(0)^{\mathrm{a}}$ & $-9.3969(13)^{\mathrm{a}}$ & $-6.9840(0)^{\mathrm{a}}$ & $-8.8859(10)^{\mathrm{a}}$ \\
\hline $\ln G C F_{t}$ & $-0.9268(0)$ & $-0.7141(3)$ & $-7.4285(1)^{\mathrm{a}}$ & $-6.3072(1)^{a}$ \\
\hline$\Delta \ln G C F_{t}$ & $-6.7187(0)^{\mathrm{a}}$ & $-6.8486(5)^{\mathrm{a}}$ & - & - \\
\hline $\ln S E R V_{t}$ & $0.9461(0)$ & $0.7514(3)$ & $-3.8190(1)^{b}$ & $-6.0289(4)^{\mathrm{a}}$ \\
\hline$\Delta \ln S E R V_{t}$ & $-4.9701(0)^{\mathrm{a}}$ & $-4.9145(10)^{\mathrm{a}}$ & - & - \\
\hline
\end{tabular}

Notes: Superscripts ${ }^{\mathrm{a}}$ and ${ }^{\mathrm{b}}$ denote significance at $1 \%$ and $5 \%$ levels respectively. $\Delta$ is first-difference operator. 
Table 2: Cointegration test

\begin{tabular}{ll}
\hline $\begin{array}{l}\text { Long-run specification } \\
(F \text {-test })\end{array}$ & $\begin{array}{l}\text { Long-run specification } \\
(F \text {-test })\end{array}$ \\
\hline Country : INDIA & $F(\mathrm{GCF} \mid \mathrm{GDPC})=2.2361$ \\
$F(\mathrm{GDPC} \mid \mathrm{GCF})=5.8859^{\mathrm{b}}$ & $F(\mathrm{SERV} \mid \mathrm{GDPC})=7.9414^{\mathrm{a}}$ \\
$F(\mathrm{GDPC} \mid \mathrm{SERV})=2.1018$ & \\
Country $:$ CHINA & $F(\mathrm{GCF} \mid \mathrm{GDPC})=2.4399$ \\
$F(\mathrm{GDPC} \mid \mathrm{GCF})=1.3126$ & $F(\mathrm{SERV} \mid \mathrm{GDPC})=0.2185$ \\
$F(\mathrm{GDPC} \mid \mathrm{SERV})=4.0678^{\mathrm{c}}$ &
\end{tabular}

Notes: The $10 \%$ critical values for $I(0)$ and $I(1)$ are 3.190 and 3.730 . The corresponding $5 \%$ and $1 \%$ critical values are $3.877,4.460$, and 5.607 and 6.193 respectively. The critical values are obtained from Narayan (2005).

Table 3: Long-run elasticities

\begin{tabular}{lccc}
\hline & \multicolumn{3}{c}{ Independent Variables } \\
\hline Country: INDIA & & $\Delta \mathrm{GCF}$ & $\Delta$ SERV \\
Dependent Variables: & & \\
$\Delta$ GDPC & & $0.6483^{\mathrm{a}}$ & \\
& & $(0.1012)$ & \\
$\Delta$ SERV & $4.5784^{\mathrm{c}}$ & & \\
& $(2.5826)$ & & $0.8105^{\mathrm{a}}$ \\
Country: CHINA & & & $(0.0354)$ \\
Dependent Variables: & & & \\
$\Delta$ GDPC & & & \\
\hline
\end{tabular}

Notes: Superscripts ${ }^{a}$ and ${ }^{c}$ denotes significance at $1 \%$ and $10 \%$ levels respectively. Standard error in parentheses. 
Table 4: Short-run elasticities

\begin{tabular}{lllll}
\hline \multicolumn{3}{c}{ Independent Variables } \\
\hline & $\Delta \mathrm{GDPC}$ & $\Delta \mathrm{GCF}$ & $\Delta \mathrm{SERV}^{-}$ & $\mathrm{ECM}_{\mathrm{t}-1}$ \\
\hline $\begin{array}{l}\text { Country: INDIA } \\
\text { Dependent Variables: }\end{array}$ & & & \\
$\Delta$ GDPC & & $0.2355^{\mathrm{a}}$ & -0.1182 \\
& & $(0.0612)$ & $(0.0744)$ \\
$\Delta$ SERV & $0.0833^{\mathrm{b}}$ & & & -0.0182 \\
& $(0.0411)$ & & & $(0.0191)$ \\
Country : CHINA & & & & \\
Dependent Variables: & & & $0.1665^{\mathrm{a}}$ & $-0.2055^{\mathrm{a}}$ \\
$\Delta$ GDPC & & $(0.0562)$ & $(0.0749)$ \\
\hline
\end{tabular}

Notes: Superscripts ${ }^{\mathrm{a}, \mathrm{b}}$ and ${ }^{\mathrm{c}}$ denote significance at $1 \%, 5 \%$ and $10 \%$ respectively. Standard error in parentheses.

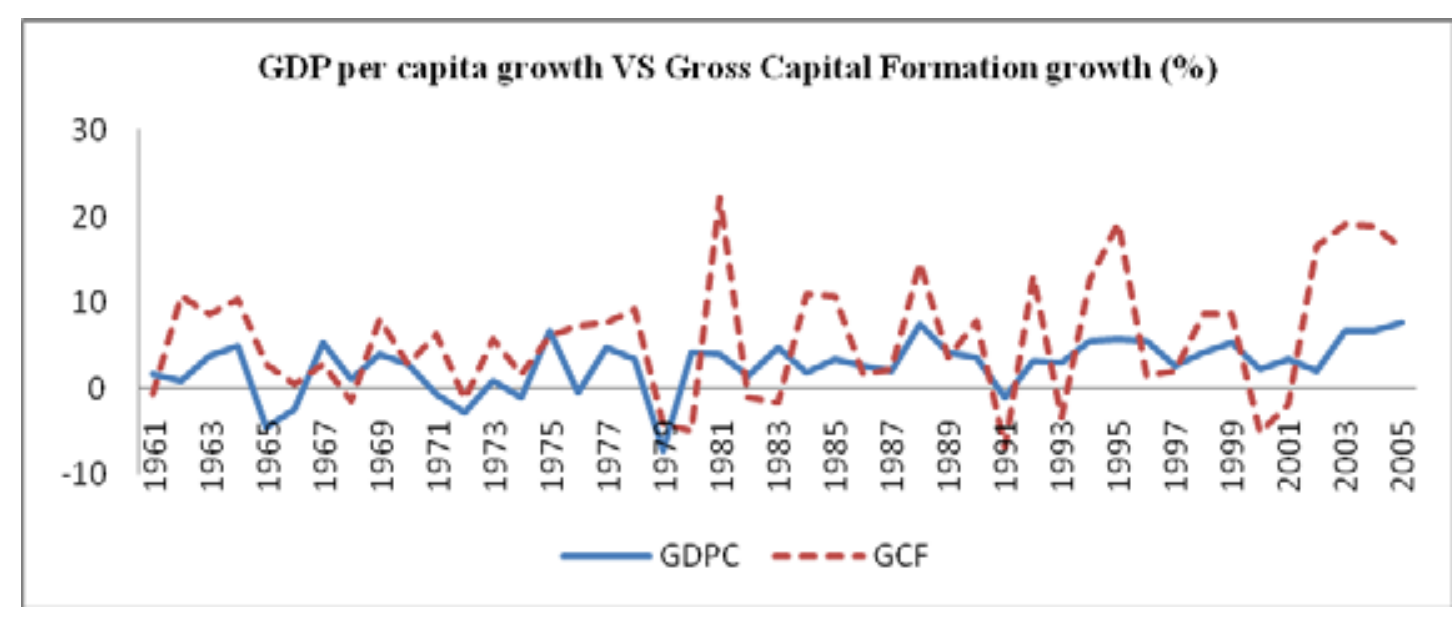

Figure 1. India

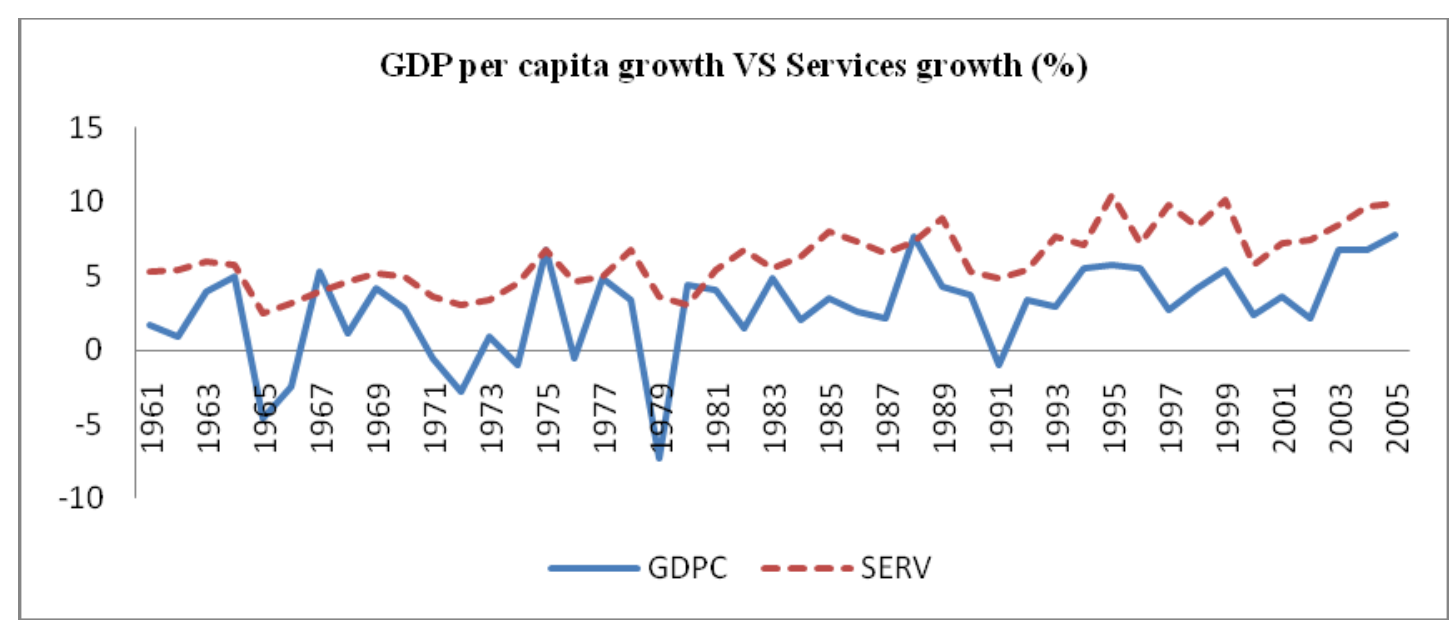

Figure 2. India 


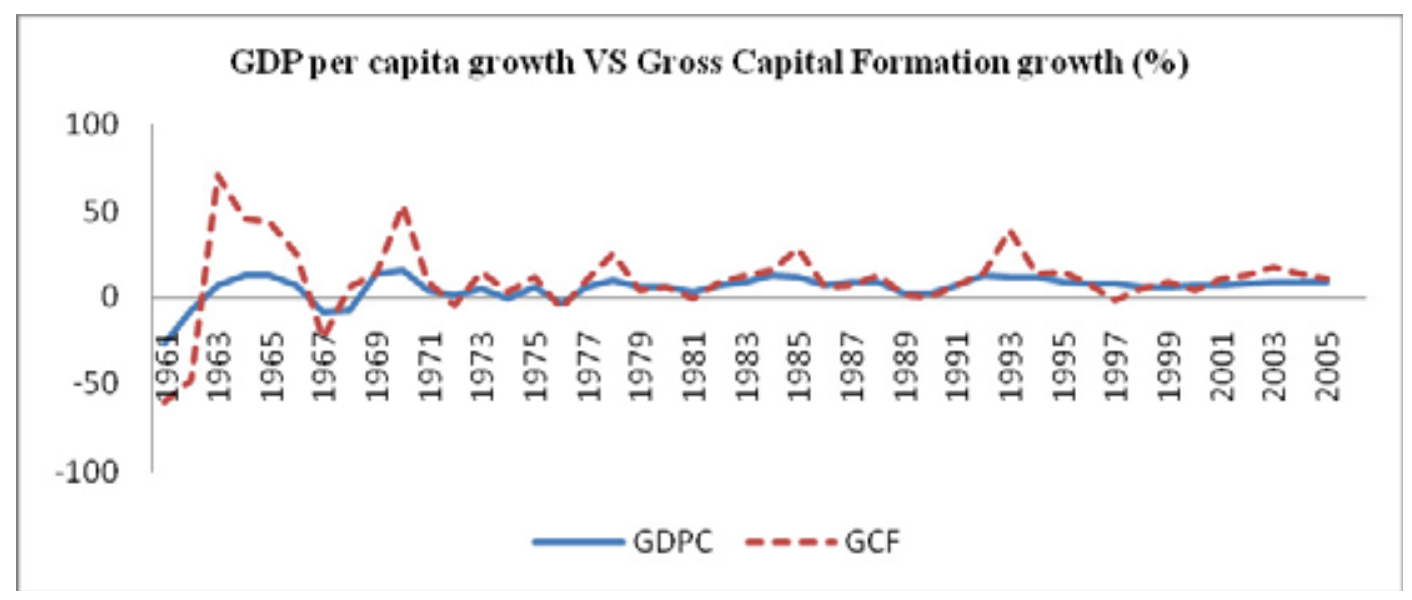

Figure 3. China

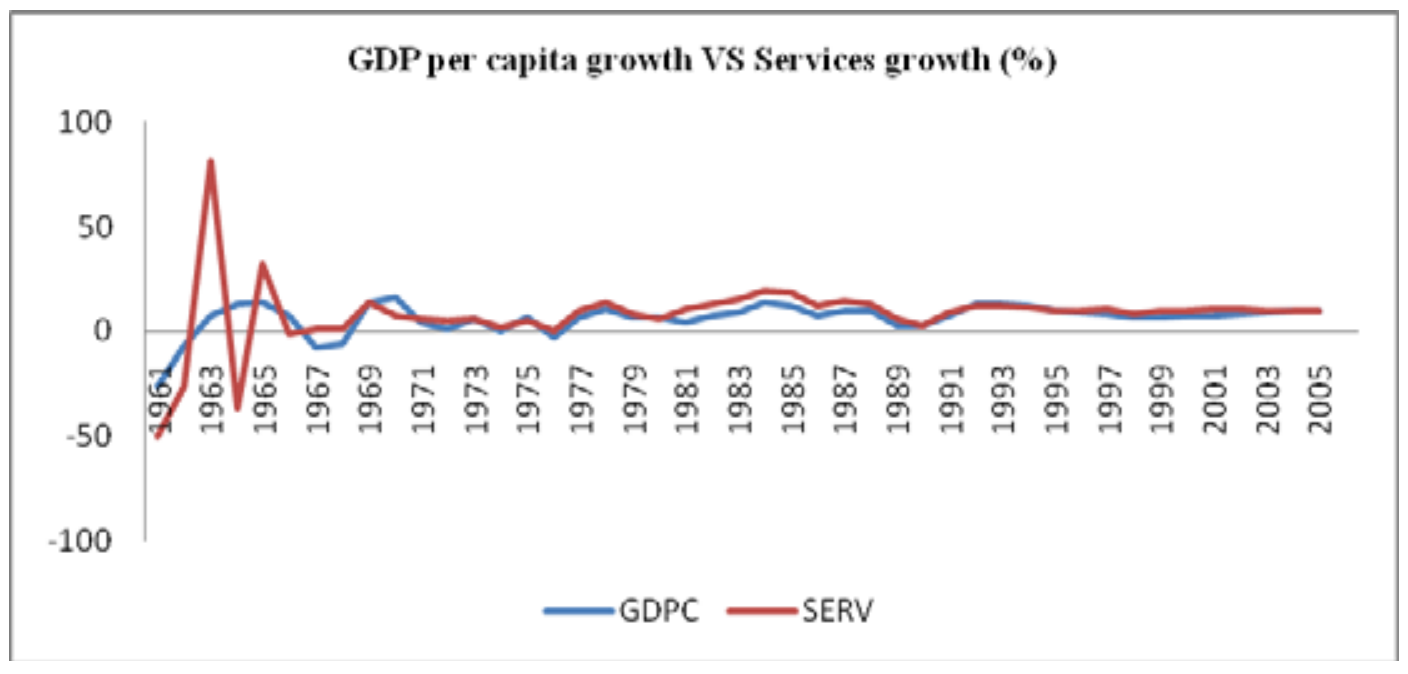

Figure 4. China 